\title{
Designer Seed for Enhancement of Yield in Cotton
}

\author{
K. Sujatha, S. Ambika
}

10.18805/IJARe.A-5211

\begin{abstract}
Field experiments were carried out at Agricultural Research Station, Vaigai Dam, to identify the performance of designer seed on yield of cotton. Seeds fortified with KCl 1\% for $6 \mathrm{~h}$ followed by polymer coating @ 3ml/ kg + Carbendazim @ $2 \mathrm{~g} / \mathrm{kg}+$ imidachloprid @ 2 ml/kg + Tichoderma viride@ $4 \mathrm{~g} / \mathrm{kg}+$ Azospirilum @ $40 \mathrm{~g} / \mathrm{kg}$. The effect was more beneficial through increased field emergence (86\%) population at maturity/plot (57.34), number of sympodial branches (13.62), number of. bolls/ plant (64.50), kapas yield/plant (71.02 $\mathrm{g}$ ), kapas yield/plot $(2.43 \mathrm{~kg})$ and seed yield/ plant $(43.72 \mathrm{~g})$ compared to untreated control $(73 \%, 48,12.04,50.99,59.67 \mathrm{~g}, 1.93 \mathrm{~kg}$ and $37.9 \mathrm{~g}$, respectively for field emergence, population at maturity/plot, number of sympodial branches, number of. bolls/plant, kapas yield/plant (g), kapas yield/plot $(\mathrm{kg})$ and seed yield/ plant $(\mathrm{g})$. Days to $50 \%$ flowering and pest and disease incidences (\%) were higher in untreated control compared to control. The per cent decrease over control was 12.5 and $52.4 \%$, respectively for days to $50 \%$ flowering and pest and disease.
\end{abstract}

Key words: Azospirilum, Cotton, Designer seed, Polymer coating, Tichoderma viride.

\section{INTRODUCTION}

Cotton is an important fibre crop of global importance, which is known as the "king" of fibre and in recent times cotton is called as the "White gold". Cotton belongs to the Malvaceae family and is the most important commercial crop. Cotton belongs to the genus Gossypium and comprises of 50 different species distributed in eight genomes, among which only four species are cultivated viz., Gossypium arboreum and Gossypium herbaceumbelonging to the old world diploid group, whereas the new world tetraploid cultivated species are Gossypium hirsutum and Gossypium barbadense. Cotton contributes about three per cent to the national GDP and generates eight per cent of central excise revenue, accounts for over 14 per cent of total industrial production.

Designer seed is an integrated pre-sowing seed treatment that involves addition of nutrients, plant protectants and bio inoculants to enhance seed quality viz., field emergence and yield attributing parameters. Seed fortification is a pre sowing seed management technique; where, essential and needy bioactive substances can be added to improving the initial stamina of the seed for higher germinability, seedling vigour and field stand. Seed fortification with plant growth regulators and inorganic nutrients has been already reported (Ponnuswamy et al., 2011 in solanaceous vegetables). Greater efficiency of seeds with $\mathrm{KCl}$ is possibly related to the osmotic advantage that $\mathrm{K}^{+}$has in improving cell water saturation, and that they act as co-factors in the activities of numerous (Taiz and Zeiger 2002). Biologicallly active products, more appropriately called microbial inoculants, containing activestrains of selective microorganisms like Azospirillum help in increasing the plant growth by biological nitrogen fixation, phosphate mobilization and nutrient uptake Trichoderma spp. are endophytic plant symbionts that are widely used as seed treatments to control diseases and to enhance plant growth
Department of Seed Science and Technology, Agricultural College and Research Institute, Madurai-625 104, Tamil Nadu, India.

Corresponding Author: K. Sujatha, Department of Seed Science and Technology, Agricultural College and Research Institute, Madurai-625 104, Tamil Nadu, India. Email: sujathakvk@gmail.com

How to cite this article: Sujatha, K. and Ambika, S. (2020). Designer Seed for Enhancement of Yield in Cotton. Indian Journal of Agricultural Research. 54(2): 217-221.

Submitted: 21-01-2019 Accepted: 17-10-2019 Published: 11-01-2020

and yield. These fungi are frequently applied as seed treatments, where they may improve plant stands and induce long-term improvements in plant quality (Harman, 2006). Therefore, seed treatments can induce both short-term and long-term improvements in seed and subsequent plant performance. Polymer coating technology is a sophisticated process of applying precise amount of active ingredients along with a liquid material directly on to the seed surface without obscuring its shape and total seed weight may increase up to 1 to 2 per cent. Smaller amounts of chemicals are needed as compared to broadcasting or surface dressing on, to the growing medium. It makes room for including all the required ingredients like inoculants, protectants, nutrients, hydrophilic substances, herbicides, oxygen suppliers etc. It ensures dust free handling of treated seed, both user and environment friendly. Polymer coating also acts as a temperature switch and protective coat in regulating the intake of water, until the soil has warmed to a pre determined temperature. An ideal polymer will not be permeable to water vapour, but will be water-soluble and allow the seed to imbibe sufficient moisture for germination without scarification. With this background the present study was undertaken to identify the performance of designer seed of cotton, for maximizing its productivity. 


\section{MATERIALS AND METHODS}

Genetically pure seeds of cotton seeds were obtained from the Agricultural Research Station, Vaigai Dam, Tamil Nadu. Seed coating polymer (Polykote) utilized for the study was obtained from M/s. Little's Oriental Balm and Pharmaceuticals Ltd., Chennai. The Polymer is a liquid based with colourant (black) substance impermeable to water vapour, easily water soluble fast drying and biodegradable and available in various colours such as red, white, green, blue, pink, yellow and black. In order to standardize the polymer coating of seeds with other ingredients, the following treatments were employed. Treatment details are

$\mathrm{T}_{1}$ : Dry seed (Control),

$\mathrm{T}_{2}$ : Dry seed - Polymer @ $3 \mathrm{ml} / \mathrm{kg}+$ imidachloprid @ $2 \mathrm{ml} /$ $\mathrm{kg}+$ Carbendazim @ $2 \mathrm{~g} / \mathrm{kg}$,

$\mathrm{T}_{3}$ : Dry seed - Polymer @ 3ml/kg + Carbendazim @ 2 g/kg + imidachloprid @ 2 ml/kg + Tichoderma viride @4 g/ $\mathrm{kg}+$ Azospirilum @ $40 \mathrm{~g} / \mathrm{kg}$,

$\mathrm{T}_{4}$ : Dry seed - Polymer @ $3 \mathrm{ml} / \mathrm{kg}$ + Carbendazim @ $2 \mathrm{~g} / \mathrm{kg}$ + imidachloprid@2 ml/kg and soil application of Tichoderma viride@1.6 kg/ac + Azospirilum@ 8000 g/ac,

$\mathrm{T}_{5}$ : Fortified seed - Seed Fortification with $1 \% \mathrm{KCl}$ for $6 \mathrm{~h}$ and drying back to original moisture content,

$\mathrm{T}_{6}$ : Fortified seed - Polymer @ 3 ml/kg + imidachloprid @ $2 \mathrm{ml} / \mathrm{kg}+$ Carbendazim @ $2 \mathrm{~g} / \mathrm{kg}$,

$\mathrm{T}_{7}$ : Fortified seed - Polymer @ $3 \mathrm{ml} / \mathrm{kg}$ + Carbendazim @ 2 $\mathrm{g} / \mathrm{kg}+$ imidachloprid @ 2 ml/kg+Tichoderma viride @ $4 \mathrm{~g} / \mathrm{kg}+$ Azospirilum @ $40 \mathrm{~g} / \mathrm{kg}$,

$\mathrm{T}_{8}$ : Fortified seed - Polymer @ $3 \mathrm{ml} / \mathrm{kg}$ + Carbendazim @ 2 $\mathrm{g} / \mathrm{kg}+$ imidachloprid @ $2 \mathrm{ml} / \mathrm{kg}$ and soil application of Tichoderma viride@1.6 kg/ac + Azospirilum @ 8000 g/ac.

The Seed fortification was done with soaking of seeds in $1 \% \mathrm{KCl}$ for $6 \mathrm{~h}$ and drying back to original moisture content. Then, the seeds were coated and air dried under shade for $24 \mathrm{~h}$ to bring back to its original moisture content or weight. All the pesticides, fungicides and biocontrol agents were mixed together and added to the polykote and thoroughly mixed with known quantity of seed for 2-3 minutes to have uniformity in coating.

A field experiment was conducted at Agricultural Research Station, Vaigai Dam, Tamil Nadu during rabi 2013 and rabi 2014 to verify the efficacy and practical utility of the designer seed coating technology. The design adopted was factorial randomized block design with three replications. The plot size adopted was $4 \times 3 \mathrm{~m}$ (12 sq.m.) with the spacing $30 \times 10 \mathrm{~cm}$. All the recommended package of practices was followed for raising of crop. Ten plants in each replication for all the treatments were tagged at random for recording the morphometric characters viz., growth parameters: field emergence, yield and yield attributes parameters viz., days to $50 \%$ flowering, number of monopodial branches/plant, number of symbodial branches/plant, kapas yield/plant $(\mathrm{g})$, kapas yield/plot $(\mathrm{kg})$, seed yield/plant $(\mathrm{g})$, plant population at maturity stage/plot and pest and disease incidence. The data collected from experiments were subjected to an Analysis of Variance and treatment differences tested ( $\mathrm{t}$ test) for its significance $(P=0.05)$ using pooled analysis after Gomez and Gomez (1984). Where ever necessary, the per cent values were transformed in to arc sine values prior to statistical analysis.

\section{RESULTS AND DISCUSSION}

Field emergence potential of seeds is the most important practical aspect of seed quality as it decides the performance of the resultant crop. Among the treatments, fortified seeds coated with $\mathrm{T}_{7}$ (Fortified seed - Polymer @ 3ml/kg + Carbendazim @ $2 \mathrm{~g} / \mathrm{kg}$ + imidachloprid @ $2 \mathrm{ml} / \mathrm{kg}+$ Tichoderma viride@ $4 \mathrm{~g} / \mathrm{kg}+$ Azospirilum @ $40 \mathrm{~g} / \mathrm{kg}$ ), improved the field emergence over untreated control by 13.7 and 22.2 per cent for 2013 and 2014, respectively (Table 1 ). The $T_{7}$ treated seeds took minimum days (65 and 70 days for 2013 and 2014 respectively) for 50 per cent flowering compared to untreated control (76 and 79 days for 2013 and 2014 respectively) (Table 1 ). Increased plant growth and yield were due to $\mathrm{KCl}$ fortification of seed which is favourable for the development of plasma colloids. Potassium has a prevalent action in plants and is involved in maintenance of ionic balance in cell and bounds ironically to enzyme pyruvate kinase which is essential in respiration and carbohydrate metabolism (Aisha et al., 2007). The beneficial effect might be due to polymer and nutrients. The improvement in field emergence could also be ascribed to activation of cells, which results in the enhancement of mitochondrial activity leading to the formation of more high energy compounds and vital bimolecules, which were made available during the early phase of germination (Kavitha, 2002). Duan and Burris (1997) reported that higher germination and field emergence percentage could be seen in polymer coated sugar beet seeds, and it was mainly due to increase in the rate of imbibitions where the fine particles in the coating acts as "wick" or moisture attracting material or perhaps to improve germination. Polymer coating increased the absorption of water, gases, micronutrients and the activity of hormones which help rapid and quick seedling emergence, faster growth and early panicle emergence in paddy.

In cotton pest and disease is a severe problem and may cause yield reduction. Pest and disease incidence was less in $T_{7}$ treated seeds (4 and 3.79\% for 2013 and 2014 respectively) compared to untreated control seed (6.8 and $9.5 \%$ for 2013 and 2014 respectively) (Table 1). Polymer coating of seed improve physical properties of the seed and provide protection from biological enemies (Bennett et al., 1992). This might be due to the presence of polymer which improved the resistance of seeds towards pest and disease in the much warranted juvenile stage, besides improving seedling vigour. Chen et al. (2004) reported that corn seeds coating with super absorbent polymer played an important role in improving the growth and inducing the activity of pest 
and disease resistance-related enzymes in seedlings for its keeping water ability and it would be beneficial to the pest and disease control.

The yield attributes viz., plant population at maturity stage/plot, number of sympodial branches /plant, number of bolls/plant, kapas yield/plant (g), kapas yield/plot $(\mathrm{kg})$ and seed yield/ plant $(\mathrm{g})$ were found to be significant. Among the treatments, $T_{7}$ (Fortified seed-Polymer @ $3 \mathrm{ml} / \mathrm{kg}+$ Carbendazim @2 g/kg + imidachloprid @ $2 \mathrm{ml} / \mathrm{kg}+$ Tichoderma viride@ @ g/kg + Azospirilum @ 40 g / kg), recorded higher plant population at maturity stage/plot, number of sympodial branches/plant, number of bolls/plant, kapas yield/plant $(\mathrm{g})$, kapas yield/plot $(\mathrm{kg})$ and seed yield/ plant $(\mathrm{g})$. The per cent increase over control was 31.8, 7.5, 18.9, 18.6, 12.6 and 18\%, respectively for 2013 and 14.1 plant population at maturity stage/plot, 16.6 number of sympodial branches /plant, 34.2 number of bolls/plant, 19.3 kapas yield/plant $(\mathrm{g}), 39.8 \mathrm{kapas}$ yield/plot $(\mathrm{kg})$ and 13.6 seed yield/ plant (g) for 2014 (Table 2, 3 and Fig 1). The reason for the increased yield might be due to the increased photosynthetic efficiency through stabilization of chlorophyll, higher production of photosynthates resulting in increased translocation of organic material from the source to sink in the treated plants. Similar findings are also reported by Chachalis and Smith (2001) in Soybean, Sabir- Ahamed (2003) in maize and Rana et al. (2001) in Indian mustard, Rajasekaran (2004) in brinjal, Vinitha (2006) in tomato, Marimuthu (2007) in rice and Vegula (2008) in maize. Yield increase due to polymer coating was reported by Chikkana et al. (2000) in groundnut; Senhur Kumaran et al. (2001) in tomato, Nisha Chandran (2003) in MCU 5 cotton, Sherin (2003) in maize, Saritha Devi (2004) in sorghum, Praveena

Table 1: Performance of integrated seed treatments on field emergence (\%), days to $50 \%$ flowering (days) and Pest and disease incidence $(\%)$ in cotton.

\begin{tabular}{|c|c|c|c|c|c|c|c|c|c|}
\hline \multirow[t]{2}{*}{ Treatments } & \multicolumn{3}{|c|}{ Field emergence (\%) } & \multicolumn{3}{|c|}{ Days to $50 \%$ flowering } & \multicolumn{3}{|c|}{$\begin{array}{l}\text { Pest and disease } \\
\text { incidence (\%) }\end{array}$} \\
\hline & 2013 & 2014 & Mean & 2013 & 2014 & Mean & 2013 & 2014 & Mean \\
\hline $\mathrm{T}_{1}$ & $70.60(57.16)$ & $75.00(60.00)$ & 72.80 & 76.00 & 78.67 & 77.34 & 6.80 & 9.59 & 8.20 \\
\hline $\mathrm{T}_{2}$ & $72.00(58.05)$ & $77.00(61.34)$ & 74.50 & 74.60 & 75.67 & 75.14 & 6.60 & 7.26 & 6.93 \\
\hline $\mathrm{T}_{3}$ & $73.60(59.08)$ & $81.00(64.15)$ & 77.30 & 72.50 & 74.33 & 73.42 & 6.30 & 5.86 & 6.08 \\
\hline $\mathrm{T}_{4}$ & $72.70(58.50)$ & $83.00(65.65)$ & 77.85 & 73.30 & 74.33 & 73.82 & 6.40 & 5.94 & 6.17 \\
\hline $\mathrm{T}_{5}$ & $72.70(58.50)$ & $83.00(65.65)$ & 77.85 & 73.60 & 70.67 & 72.14 & 6.60 & 4.26 & 5.43 \\
\hline $\mathrm{T}_{6}$ & $74.00(59.34)$ & $86.67(68.58)$ & 80.34 & 72.30 & 69.33 & 70.82 & 5.50 & 4.03 & 4.77 \\
\hline $\mathrm{T}_{7}$ & $80.30(63.65)$ & $91.67(73.22)$ & 85.99 & 70.00 & 65.33 & 67.67 & 4.00 & 3.79 & 3.90 \\
\hline $\mathrm{T}_{8}$ & $78.00(62.02)$ & $89.33(70.93)$ & 83.67 & 71.60 & 67.00 & 69.30 & 4.50 & 3.83 & 4.17 \\
\hline \multirow[t]{2}{*}{ Mean } & $74.24(59.53)$ & 83.33(65.69) & 78.79 & 72.99 & 71.92 & 72.45 & 5.84 & 5.57 & 5.70 \\
\hline & $\mathbf{T}$ & S & $T \times S$ & $\mathbf{T}$ & S & $T \times S$ & $\mathbf{T}$ & S & $T \times S$ \\
\hline SEd & 1.28 & 0.64 & 1.81 & 1.19 & 0.59 & 1.68 & 0.09 & 0.04 & 0.13 \\
\hline$C D(0.05)$ & $2.62^{* *}$ & $1.31^{* *}$ & $3.71^{* *}$ & $2.44^{* *}$ & $1.22^{* *}$ & $3.45^{* *}$ & $0.19^{* *}$ & $0.09^{* *}$ & $0.28^{* *}$ \\
\hline
\end{tabular}

(Figs in parentheses are arc sine transformed values)

T- Treatment, S- Season, T $\times$ S- Treatment $\times$ Season, ${ }^{* *}$ - Significant at $5 \%$ level.

Table 2: Performance of integrated seed treatments on number of sympodial branches, number of monopodial branches and number of bolls/plant in cotton.

\begin{tabular}{|c|c|c|c|c|c|c|c|c|c|}
\hline \multirow[t]{2}{*}{ Treatments } & \multicolumn{3}{|c|}{ Number of sympodial branches } & \multicolumn{3}{|c|}{ Number of monopodial branches } & \multicolumn{3}{|c|}{ Number of bolls/plant } \\
\hline & 2013 & 2014 & Mean & 2013 & 2014 & Mean & 2013 & 2014 & Mean \\
\hline $\mathrm{T}_{1}$ & 9.30 & 14.77 & 12.04 & 3.80 & 4.37 & 4.09 & 51.30 & 50.67 & 50.99 \\
\hline $\mathrm{T}_{2}$ & 9.50 & 15.87 & 12.69 & 3.60 & 3.17 & 3.39 & 54.60 & 55.33 & 54.97 \\
\hline $\mathrm{T}_{3}$ & 9.70 & 15.77 & 12.74 & 3.30 & 2.97 & 3.14 & 56.30 & 55.67 & 55.99 \\
\hline $\mathrm{T}_{4}$ & 9.60 & 15.47 & 12.54 & 3.40 & 3.37 & 3.39 & 56.00 & 53.67 & 54.84 \\
\hline $\mathrm{T}_{5}$ & 9.60 & 16.27 & 12.94 & 3.50 & 2.67 & 3.09 & 55.30 & 62.67 & 58.99 \\
\hline $\mathrm{T}_{6}$ & 10.00 & 16.67 & 13.34 & 3.20 & 3.70 & 3.45 & 58.60 & 64.33 & 61.47 \\
\hline $\mathrm{T}_{7}$ & 10.00 & 17.23 & 13.62 & 2.90 & 4.63 & 3.77 & 61.00 & 68.00 & 64.50 \\
\hline $\mathrm{T}_{8}$ & 10.00 & 16.93 & 13.47 & 3.00 & 4.40 & 3.70 & 59.00 & 65.33 & 62.17 \\
\hline \multirow[t]{2}{*}{ Mean } & 9.71 & 16.12 & 12.92 & 3.34 & 3.66 & 3.50 & 56.51 & 59.46 & 57.99 \\
\hline & $\mathbf{T}$ & S & $T \times S$ & $\mathbf{T}$ & $S$ & $T \times S$ & $\mathbf{T}$ & $S$ & $T \times S$ \\
\hline SEd & 0.40 & 0.20 & 0.56 & 0.17 & 0.08 & 0.24 & 1.68 & 0.84 & 2.38 \\
\hline CD (0.05) & $0.82^{* *}$ & $0.41^{* *}$ & $1.16^{* *}$ & $0.35^{* *}$ & $0.17^{* *}$ & $0.49^{\star *}$ & $3.45^{* *}$ & $1.72^{* *}$ & $4.88^{* *}$ \\
\hline
\end{tabular}

T- Treatment, S- Season, T $\times$ S- Treatment $x$ Season, ${ }^{* *}$ - Significant at $5 \%$ level. 
Designer Seed for Enhancement of Yield in Cotton

Table 3: Performance of integrated seed treatments on kapas yield/plant $(\mathrm{g})$, kapas yield/plot $(\mathrm{kg})$ and seed yield/plant $(\mathrm{g})$ in cotton.

\begin{tabular}{lccccccccc}
\hline Treatments & \multicolumn{3}{c}{ Kapas yield/plant $(\mathrm{g})$} & \multicolumn{3}{c}{ Kapas yield/plot $(\mathrm{kg})$} & \multicolumn{2}{c}{ Seed yield / plant (g) } \\
\cline { 2 - 10 } & 2013 & 2014 & Mean & 2013 & 2014 & Mean & 2013 & 2014 & Mean \\
\hline $\mathrm{T}_{1}$ & 52.00 & 67.33 & 59.67 & 1.97 & 1.88 & 1.93 & 33.80 & 41.37 & 37.59 \\
$\mathrm{~T}_{2}$ & 53.70 & 69.97 & 61.69 & 1.99 & 1.94 & 1.97 & 34.90 & 42.57 & 38.74 \\
$\mathrm{~T}_{3}$ & 57.00 & 72.00 & 64.50 & 2.05 & 2.03 & 2.04 & 37.10 & 43.53 & 40.32 \\
$\mathrm{~T}_{4}$ & 56.00 & 70.67 & 63.34 & 2.03 & 1.97 & 2.00 & 36.40 & 42.70 & 39.55 \\
$\mathrm{~T}_{5}$ & 55.30 & 75.33 & 65.32 & 2.01 & 2.17 & 2.09 & 36.00 & 45.60 & 40.80 \\
$\mathrm{~T}_{6}$ & 57.70 & 76.67 & 67.19 & 2.08 & 2.27 & 2.18 & 37.50 & 46.13 & 41.82 \\
$\mathrm{~T}_{7}$ & 61.70 & 80.33 & 71.02 & 2.22 & 2.63 & 2.43 & 39.90 & 48.53 & 43.72 \\
$\mathrm{~T}_{8}$ & 58.00 & 78.33 & 68.17 & 2.09 & 2.43 & 2.26 & 37.70 & 47.03 & 42.37 \\
Mean & $\mathbf{5 6 . 4 3}$ & $\mathbf{7 3 . 7 9}$ & $\mathbf{6 5 . 1 1}$ & $\mathbf{2 . 0 6}$ & $\mathbf{2 . 1 7}$ & $\mathbf{2 . 1 1}$ & $\mathbf{3 6 . 5 4}$ & $\mathbf{4 4 . 6 8}$ & $\mathbf{4 0 . 6 1}$ \\
& $\mathbf{T}$ & $\mathbf{S}$ & $\mathbf{T} \mathbf{x} \mathbf{S}$ & $\mathbf{T}$ & $\mathbf{S}$ & $\mathbf{T} \times \mathbf{~ S}$ & $\mathbf{T}$ & $\mathbf{S}$ & $\mathbf{T} \mathbf{x} \mathbf{S}$ \\
SEd & 1.34 & 0.67 & 1.90 & 0.08 & 0.04 & 0.11 & 0.93 & 0.46 & 1.31 \\
CD (0.05) & $2.76^{* *}$ & $1.38^{* *}$ & $3.90^{* *}$ & $0.16^{* *}$ & $0.08^{* *}$ & $0.23^{* *}$ & $1.90^{* *}$ & $0.95^{* *}$ & $2.69^{* *}$ \\
\hline
\end{tabular}

T- Treatment, S- Season, T $\times$ S - Treatment $\times$ Season, ${ }^{* *}$ - Significant at $5 \%$ level.

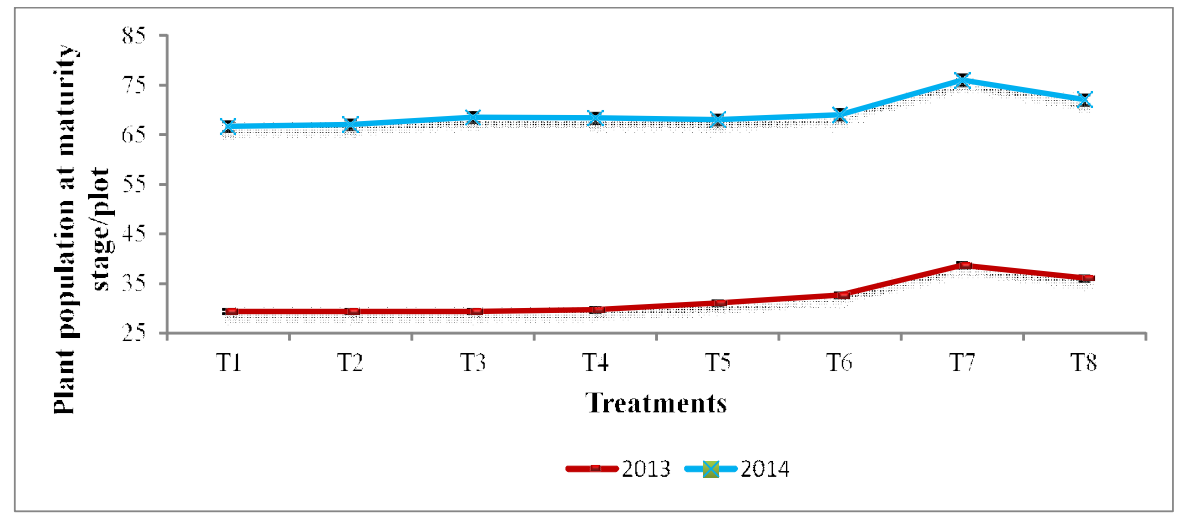

Fig 1: Performance of integrated seed treatments on plant population at maturity stage/plot in cotton.

(2005) in cotton and Natesan (2006) in blackgram and Shakuntala et al. (2010) in sunflower hybrid.

The yield increase could be attributed to the presence of inoculants, protectants, nutrients and polymer in the coating treatment. Growth promotion by Trichoderma which is attributed to solublization and sequestration of many plant nutrients such as $\mathrm{P}, \mathrm{Mn}, \mathrm{Fe}$ and $\mathrm{Zn}$ and supply to the plants, which in turn into increased plant growth (Lal et al., 2013). The increased yield was attributed to increase in plant stand and plant establishment with suppression of seed borne pathogens. Inhibition of the activity of the pathogen resulted in more total dry matter production which facilitates more availability of photosynthates for sink and ultimately resulted in increased yield. Similar findings were observed by Sunil Kumar et al. (2009) in soybean. Azospirillum inoculation is mainly attributed to increased growth due to increase root biomass and accumulation of nitrogen and the production of gibberellins and cytokinin like substances which promote the growth of the seedlings. There are many reports that seed inoculation of Azospirillum, increased biomass and grain yield (Woodard and Bly, 2000) increased cob length and cob weight (Cavallet et al., 2000).

\section{CONCLUSION}

It can be concluded that designer seed treatments of seeds fortified with $\mathrm{KCl} 1 \%$ + Polymer @ $3 \mathrm{ml} / \mathrm{kg}$ of seeds + Carbendazim@2g/kg + imidachloprid@2 ml / kg + Tichoderma viride@ @ g / kg + Azospirilum @ 40 g / kg recorded higher yield attributing characters and less incidence of pest and disease in cotton.

\section{REFERENCES}

Aisha, A.H., Rizk, F.A., Shaheen, A.M. and Abdel-Mouty M.M. (2007). Onion plant growth, bulb yield and its physical and chemical properties as affected by organic and natural fertilization. Res. J. Agric. Biol. Sci. 3(5): 380-388.

Bennett, M., Fritz, V.A. and Callan, N.W. (1992). Impact of seed treatments on crop stand establishment. Hort. Tech. 2: 345-349.

Cavallet, L.E., Pessoa, A.C.D.P. and Helmich, J.J. (2000). Corn productivity in response to nitrogen application and seed inoculation with Azospirillum spp. Revista Brasileira deEngluharia Agricolal Ambiental. 4(1): 129-132.

Chachalis, D. and Smith, M. L. (2001). Hydrophobic polymer application reduces imbibition rate and partially improves 
germination or emergence of soybean seedlings. Seed Sci. and Technol. 29: 91-98.

Chen, H., Jiang, S., Zhou, J., Zhao, Y., Zhao, Y. and Wang, J. (2004). Super absorbent polymer seed coating and its effect on physiological features of corn seed. Natural Sci. 27(3): 30-35.

Chikkanna, C.S., Thimmegowda, Paramesh, R. and Devakumar, N. (2000). Hydrophilic polymers seed treatment on seed quality and yield in finger millet, cowpea and groundnut. Seeds and Farms. 85: 39-45.

Duan, X. and Burris, J.S. (1997). Film coating impairs leaching of germination inhibitions in Development, Chinese Association of Agricultural Sciences, DOA, Ministry of Agriculture, Beijing, China Agriculture Press, pp. 737-747.

Gomez, K.A. and Gomez, A.A. (1984). Statistical Procedures for Agricultural Research. John Willey and Sons, New York.

Harman, G.E. (2006). Overview of mechanisms and uses of Trichoderma spp. Phytopathology. 96:190-194.

Kavitha, S. (2002). Seed hardening and pelleting for maximising the productivity of blackgram [Vigna mungo (L.) Hepper] cv. Vamban 3 under rainfed conditions. M.Sc. (Ag.) thesis, Tamil Nadu Agricultural University, Coimbatore.

Lal, G., Saini, I.P., Mehta, R.S., Maheria, S.P. and Yash Sharma. (2013). Effect of irrigation and different seed treatment methods on growth and yield of fenugreek (Trigonella foenum graecum L.). Int. J. Seed Spices. 3(2): 29-33.

Marimuthu, A. (2007). Comprehensive seed enhancement technique for direct sown rice (Oryza sativa L.) cv. CO43. M.Sc., (Ag.) Thesis, Tamil Nadu Agricultural University, Coimbatore.

Natesan P. (2006). Designing integrated seed treatment in black gram [Vigna mungo (L.) Hepper] for irrigated and rainfed ecosystem. Ph.D. Thesis. Tamil Nadu Agricultural University. Coimbatore.

Nisha Chandran. (2003). Standardization of acid delinting, storability of acid delinted seeds and polymer seed coating in cotton cv. MCU5. M.Sc. (Ag) Thesis. Tamil Nadu Agricultural University Coimbatore.

Ponnuswamy, A.S. and Vijayalakshmi, V. (2011). Effect of seed fortification with bio -inoculants, nutrients and growth regulators on seed germination and seedling vigour of tomato (Lycopersicon esculentum), brinjal (Solanum melongena) and chilli (Capsicum annum). Madras Agric. J. 98 (7-9): 251-252.

Praveena, K. (2005). Seed quality enhancement techniques in cotton (Gossypium spp). M.Sc., (Ag.) Thesis, Tamil Nadu Agricultural University, Coimbatore.
Rajasekaran, R. (2004). Investigation on seed production, enhancement and storage techniques in Brinjal hybrid COBH 1 (Solanum melongena L.) and its parental lines. Ph.D. Thesis, Tamil Nadu Agricultural University, Coimbatore.

Rana, K.S., Ashok Kumar and Gautam, R.C. (2001). Effect of starch polymer Jalashakthi on yield attributes, yield and water use efficiency of mustard under rainfed conditions. Crop Res. 22(3): 395-397.

Sabir-Ahamed A. (2003). Hybrid seed yield maximization through supplemental nutrition, hybrid vigour assessment and seed quality enhancement by polykote coating in ADTRH 1 and CORH 2 rice hybrids and their parents. Ph.D. (Ag.) Thesis, Tamil Nadu Agricultural University, Coimbatore.

Saritha Devi, J. (2004). Studies on film coating technique to improve field performance of sorghum cv. APK 1. M. Sc. (Ag.) Thesis, Tamil Nadu Agricultural University, Coimbatore.

Senhur Kumaran, S., Natarajan, S., Muthvel, J. and Sathiyamurthy, V.A. (2001). Standardization of hydrophilic polymers on growth and yield of tomato. J. Madras Agric. 88(1-3): 103-105.

Shakuntala, N.M., Vyakaranahal, B.S., Shankergouda, I., Deshpande, V.K., Pujari, B.T. and Nadaf, H.L. (2010). Effect of seed polymer coating on growth and yield of sunflower hybrid RSFH-130. Karnataka J. Agric. Sci. 23 (5): 708-711.

Sherin, (2003). Film coating technology using polykote for maximizing the planting value, growth and productivity of maize cv. CO 1. M. Sc. (Ag.) Thesis, Tamil Nadu Agricultural University, Coimbatore.

Sunil Kumar, S., Rajeswari, B., Meena Kumari, K.V. S., Ganesh, M. and Ankaiah, R. (2009). Evaluation of seed treatments using bio-agents and fungicides on seed quality and yield of soybean genotypes. J. of Oil Seeds Res. 26: 520523.

Vegulla, S. (2008). Standardization of polymer coating technology for mechanization in maize hybrid $\mathrm{COH}$ (M) 5 M. Sc. (Ag.) Thesis, Tamil Nadu Agricultural University, Coimbatore.

Taiz, L. and Zeiger, E. (2002). Plant Physiology. $3^{\text {rd }}$ ed, Sinaure Associates, Inc. Publishers, Su and Land, Massachusetts.

Vinitha, G. (2006). Flim coating and pelleting technology to augment the seed quality in tomato (Lycopersicon esculentum Mill.) cv. PKM1. M.Sc. (Ag.) Thesis, Tamil Nadu Agricultural University, Coimbatore.

Woodard, H.J. and Bly, A. (2000). Maize growth and yield responses to seed inoculated $\mathrm{N}_{2}$ fixing bacteria under dry land production conditions. J. Plant Nutrition. 23 (1): 55-65. 